\title{
Effect of Combination of Aroma Therapy Lavender and Classical Music Towards a Decrease in Anxiety Levels Moderate and Severe on Third Trimester Pregnant Women
}

\author{
Risqi Dewi Aisyah, S. Suparni, F. Fitriyani \\ Institute of Health Science, Muhammadiyah Pekajangan, Pekalongan, Indonesia \\ aisyahrisqidewi@gmail.com
}

\begin{abstract}
Anxiety disorders are more common in women than men, ie during the pregnancy period and occur during pregnancy and after childbirth, pregnancy anxiety disorders are associated with the occurrence of preterm birth, low birth weight, and decreased apgar score when the baby is born. The purpose of this study was to determine the effect of a combination of lavender aroma therapy and classical music to overcome anxiety in third trimester pregnant women before and as soon as given a combination of lavender and classical music aromatherapy. The type of research used is a quasy experiment. The sample of this study used Cluster random sampling which is 50 trimester III pregnant women. The data collection used the Hamilton Rating Scale for Anxiety (HRS-A) questionnaire, and before that an ethical test was conducted, the analysis of the study used the T Test. The results showed that there was a very significant difference between the level of anxiety before and after being given a combination of lavender aromatherapy and classical music for the anxiety of third trimester pregnant women $(\mathrm{p}=0.001<0.05)$. The effects of lavender aromatherapy are similar to the effects of classical music which have similar calming effects, balance, comfort, a sense of openness and trust, while also reducing stress, pain, anxiety. Suggestions for midwives detect the risk of anxiety and provide interventions to reduce anxiety with natural or non-pharmacological techniques.
\end{abstract}

Keywords: Aromatherapy, Anxiety, Lavender, Music

Received July, 25, 2019; Revised August 24, 2019; Accepted September 13, 2019 


\section{STRADA Jurnal Ilmiah Kesehatan}

DOI: $10.30994 /$ sjik.v8i2.218

ISSN: 2252-3847 (print); 2614-350X (online)

Vol.8 No.2. November 2019. Page.117-122

\section{BACKGROUND}

Research has identified that women who during pregnancy experience psychological disorders will result in non-optimal births including increased mortality and morbidity (Staneva, Bogossian, Pritchard, \& Wittkowski, 2015).

Anxiety disorders are more common in women than men, ie during the pregnancy period and occur during pregnancy and after childbirth, pregnancy anxiety disorders are associated with the occurrence of preterm birth, low birth weight, and decreased apgar score when the baby is born(Nath et al., 2018).

Anxiety, depression and anxiety during pregnancy are risk factors for mother and baby. More specifically, anxiety in pregnancy can result in shorter gestational age and nerve development that is detrimental to the fetus. Due to tension and anxiety during pregnancy associated with low birth weight babies, and tend to experience depression during childbirth (Schetter, Tanner, \& Angeles, 2015).

Pregnant women who experience anxiety, depression and stress increase the risk of psychological impact between mother and fetus, including bond disorders with the fetus and newborn, difficulty in adjusting psychologically the mother after giving birth, and postpartum depression (Staneva et al., 2015).

One effective way to relieve stress, anxiety and depression is by complementary techniques, including massage, aromatherapy, which has recently attracted some researchers (Kianpour, 2018).

In some studies aromatherapy was able to reduce anxiety, in this study the anxiety of pregnant women. The aroma therapy oil used is oil essencial which has the power to rejuvenate the mind, body, emotions, and spirit. Aromatherapy provides benefits from stress and anxiety that leads to conception, through all pregnancies during labor and childbirth. The aroma of lavender therapy helps reduce anxiety, stimulates circulation and has a very calming effect on the mother (Hobbs, n.d.).

Other simple relaxation techniques can be used to relieve stress and anxiety during pregnancy. Music therapy is one of the effective relaxation techniques for anxiety and stress relief during pregnancy. The results show that music therapy is effective in reducing anxiety and depression among high-risk pregnant women (Nwebube, Glover, \& Stewart, 2017). The purpose of this study was to determine the effect of a combination of lavender aroma therapy and classical music to overcome anxiety in third trimester pregnant women before labor.

\section{OBJECTIVE}

This study aimed to determine the effect of a combination of lavender aroma therapy and classical music to overcome anxiety in third trimester pregnant women before and as soon as given a combination of lavender and classical music aromatherapy.

\section{METHODS}

The type of research used is a quasy experiment. The variable measured is anxiety. This variable was measured before being given a combination of lavender aroma therapy with classical music (Pre test) and after being given a combination of lavender aroma therapy with classical music (Post test), then the difference in results was seen. The study sample used cluster random sampling, from 27 Puskemas in Pekalongan District in the Cluster to 5 Puskesmas, namely Doro I Health Center, Bojong, Karangdadap, Kedungwuni I and Kedungwuni II obtained 50 trimester III pregnant women. Data collection used the Hamilton Rating Scale for Anxiety questionnaire (HRS-A) to measure the third trimester mother's 


\section{STRADA Jurnal Ilmiah Kesehatan}

DOI: $10.30994 /$ sjik.v8i2.218

ISSN: 2252-3847 (print); 2614-350X (online)

Vol.8 No.2. November 2019. Page.117-122

anxiety level. Before the research was conducted, researchers first applied ethical clearance to the Ethics Institute of the University of Muhammadiyah Semarang, after passing the ethical test and leaving the certificate, a study was conducted

\section{RESULTS}

Table 1 Frequency of Anxiety Levels Before and After Giving a Combination of Aromatherapy and Classical Music

\begin{tabular}{lcccc}
\hline \multirow{2}{*}{ Anxiety Levels } & \multicolumn{2}{c}{ Before } & \multicolumn{3}{c}{ After } \\
\cline { 2 - 5 } & F & \% & F & \% \\
\hline None & 0 & 0 & 37 & 49,3 \\
\hline Mild & 0 & 0 & 11 & 14,7 \\
\hline Moderate & 20 & 26,7 & 2 & 2,7 \\
Severe & 27 & 36,0 & 0 & 0 \\
Severe Glossly Disabling & 3 & 4,0 & 0 & 0 \\
\hline & 50 & 100 & 50 & 100 \\
\hline
\end{tabular}

Based on the table above, it can be seen that the level of anxiety before and after the combination of aromatherapy and classical music can be seen to decrease.

Table 2 The results of the T-Test test influence the combination of aromatherapy and classical music

\begin{tabular}{llcccccc}
\hline Anxiety Levels & Mean & Beda Mean & P Value & R & CI & Lower & CI Upper \\
\cline { 1 - 4 } Before & 30,50 & \multirow{2}{*}{17.820} & 0,001 & 0,15 & 15.766 & 19.874 \\
\cline { 1 - 2 } & 12,68 & & & & & \\
\hline
\end{tabular}

Table 2 shows that the average level of anxiety before is 30.50 and the average level of anxiety is 12,68 . There is a significant decrease in the average value of anxiety levels of 17.82. From the results of statistical tests using paired $\mathrm{T}$ test $\mathrm{p}=0.001(<0.05)$ with $95 \%$ confidence interval can be there is a very significant difference between anxiety levels before and after given a combination of lavender aromatherapy and classical music for the anxiety of third trimester pregnant women.

\section{DISCUSSION}

The results showed that there were significant changes in anxiety levels before and after administration of a lavender aromatherapy combination with classical music.

Anxiety in pregnancy varies greatly, the results of the study show that anxiety increases in the third trimester, and occurs in mothers who are first pregnant. Anxiety is also associated with the risk of secondary section surgery, it should be a concern for health workers to detect women with a high risk of anxiety and fear. Health workers need to implement interventions to reduce anxiety and pregnant women can give birth normally. Increased anxiety in pregnant women before labor can be reduced by appropriate intervention and attention (Kalayil, Sheila, Souza, \& Subrahmanya, 2015). 


\section{STRADA Jurnal Ilmiah Kesehatan}

DOI: $10.30994 /$ sjik.v8i2.218

ISSN: 2252-3847 (print); 2614-350X (online)

Vol.8 No.2. November 2019. Page.117-122

An general there are two types of interventions that can be done to reduce anxiety, namely pharmacology and non-pharmacology. For non-formacology, it is widely used is complementary therapy, one of which is aromatherapy. Aromatherapy that is often used is related to anxiety and has a relaxing effect, reduces anxiety, reduces pain, improves calmness is lavender aromatherapy. Linalool and Linalyl acetate in this plant can also stimulate the parasympathetic system; Linalyl acetate also has anesthetic properties, and Linalool acts as a sedative (Maisi, Widyawati, Suwondo, \& Kusworowulan, 2017).

Lavender aromatherapy given to pregnant women not only provides psychological effects but also physiological. Aroma therapy is believed to be able to reduce tension, anxiety and anger (Trial, 2013).

The results of other studies also showed a significant effect on reducing blood pressure in pregnant women after being given aromatherapy. In addition, aromatherapy can also improve the quality of sleep in pregnant women who have high blood pressure (Maisi et al., 2017) . Balls from aromatherapy have a direct effect on the human brain. The scent is captured by receptors in the nose which then transmit further information to the brain region that controls and is associated with mood, emotion, memory that provides information to the hypothalamus which is the regulator of the internal system, including the system to regulate body temperature and heart rate. Inhaling aromatherapy lavender will increase alpha brain waves and it is this wave that creates a feeling of relaxation (Hwang, 2006).

Another nonpharmacological intervention that can be used is music. Music has a therapeutic effect on the body and mind, which is neutralizing negative emotions. Music can reduce the stress threshold and help achieve a relaxed state (Shin \& Kim, 2011). In recent years, the influence of musical intervention and music therapy has experienced increasing attention in the literature. It has been proven that music has a positive effect on cognitive and physical performance, such as concentration and endurance, as well as psychological parameters, such as anxiety and relaxation. Medical studies in particular increasingly show that music can be used as an intervention to eliminate anxiety, stress and pain. Music is therefore seen in real practice as a supplement to conventional forms of pharmacological and nonpharmacological treatments and its tendency to increase. Studies involving musical intervention in the obstetric field have shown, among other things, that music increases relaxation during pregnancy and can reduce anxiety (Herdecke \& Wulff, 2017). Other research shows that listening to music during pregnancy is fun, cheap and free of stress which may also benefit the future of the child (Nwebube et al., 2017).

This study combines the use of lavender aroma therapy with classical music, the results of this study show that this combination can reduce the anxiety of third trimester pregnant women before labor. The results of this study in line with other studies reveal that the combination of lavender aromatherapy and classical music therapy has the highest effect in lowering blood pressure in pregnant women with hypertension compared to aromatherapy lavender or music therapy alone. This combination at the same time can simultaneously reduce blood pressure in pregnant women with hypertension. Can increase alpha and beta type brain waves, where these waves will form to create a relaxed state. The effects of lavender aromatherapy are similar to the effects of classical music which have similar calming effects, balance, comfort, a sense of openness and trust, while also reducing stress, pain, anxiety, imbalanced emotions, hysteria, frustration, and providing a sense of relaxation that can affect blood pressure heart rate and breathing (Maisi et al., 2017). 


\section{STRADA Jurnal Ilmiah Kesehatan}

DOI: $10.30994 /$ sjik.v8i2.218

\section{CONCLUSION}

The conclusion in this study is that there is a very significant difference between the level of anxiety before and after the combination of lavender aromatherapy and classical music was given to the anxiety of third trimester pregnant women with a $\mathrm{P}$ value $=0.001$. Suggestions for health workers, especially midwives, should provide psychological attention, especially in third trimester pregnant women who experience anxiety before delivery, detect the risk of anxiety and provide interventions to reduce anxiety with natural or non-pharmacological techniques.

\section{REFERENCES}

Herdecke, U., W., \& Wulff, V. (2017). Music in Obstetrics: An Intervention Option to Reduce Tension, Pain and Stress Musik in der Geburtshilfe: eine Interventionsmöglichkeit zur Anspannungs- , Schmerz- und Stressreduktion Authors, 967-975.

Hobbs, V. (n.d.). Aromatherapy in Pregnancy, Labour, Birth \& Postpartum.

Kalayil, G., Sheila, M., Souza, D., \& Subrahmanya, K. (2015). International Journal of Africa Nursing Sciences Prevalence of pregnancy anxiety and associated factors, 3, 1-7. https://doi.org/10.1016/j.ijans.2015.06.002.

Maisi, S., Widyawati, M., N., Suwondo, A., \& Kusworowulan, S. (2017). EFFECTIVENESS OF LAVENDER AROMA THERAPY AND CLASSICAL MUSIC THERAPY IN LOWERING BLOOD PRESSURE IN PREGNANT, 3(6), 750-756.

Nath, S., Ryan, E., G., Trevillion, K., Bick, D., Demilew, J., Milgrom, J., \& Howard, L., M. (2018). Prevalence and identification of anxiety disorders in pregnancy: the diagnostic accuracy of the two-item Generalised Anxiety Disorder scale ( GAD-2 ), 1-10. https://doi.org/10.1136/bmjopen-2018-023766.

Nwebube, C., Glover, V., \& Stewart, L. (2017). Prenatal listening to songs composed for pregnancy and symptoms of anxiety and depression: a pilot study, 1-5. https://doi.org/10.1186/s12906-017-1759-3.

Schetter, C., D., Tanner, L., \& Angeles, L. (2015). HHS Public Access, 25(2), 141-148. https://doi.org/10.1097/YCO.0b013e3283503680. Anxiety.

Shin, H., S., \& Kim, J., H. (2011). Music Therapy on Anxiety, Stress and Maternal-fetal Attachment in Pregnant Women During Transvaginal Ultrasound. Asian Nursing Research, 5(1), 19-27. https://doi.org/10.1016/S1976-1317(11)60010-8.

Staneva, A., Bogossian, F., Pritchard, M., \& Wittkowski, A. (2015). The effects of maternal depression, anxiety, and perceived stress during pregnancy on preterm birth: A systematic review. Women and Birth, 28(3), 179-193. https://doi.org/10.1016/j.wombi.2015.02.003. 
STRADA Jurnal Ilmiah Kesehatan

DOI: $10.30994 /$ sjik.v8i2.218

ISSN: 2252-3847 (print); 2614-350X (online)

Vol.8 No.2. November 2019. Page.117-122

Trial, A., R., C. (2013). Physical and Psychologic Effects of Aromatherapy Inhalation on Pregnant Women:, 19(10), 805-810. https://doi.org/10.1089/acm.2012.0103. 